\title{
PENGARUH LIKUIDITAS, SOLVABILITAS, FIRM SIZE, DAN FIRM GROWTH TERHADAP PROFITABILITAS
}

\author{
Rahel Julietha ${ }^{1}$ dan Khairina Natsir ${ }^{2}$ \\ Program Studi Manajemen Fakultas Ekonomi dan Bisnis Universitas Tarumanagara, Jakarta \\ rahel.115170354@stu.untar.ac.id
}

\begin{abstract}
The purpose of this study is to examine the influence of liquidity, solvability, firm size, and firm growth on profitability on manufacturing companies in sector of consumer goods listed in Indonesia Stock Exchange in the period 2015-2019. This study used 42 samples of manufacturing companies in the consumer goods industrial through purposive sampling method. Data were accessed through the firm's website, www.idx.co.id and www.idnfinancial.com. Data processing using software E-views11. The result of this study shows that Firm Size has a positive significant effect on profitability. Meanwhile, Liquidity, Solvability, and Firm Growth have a negetive no significant effect on profitability.
\end{abstract}

Keywords: Profitability (ROE), Liquidity, Solvability, Firm Size, Firm Growth.

\begin{abstract}
Abstrak: Tujuan penelitian ini adalah untuk mengetahui pengaruh likuiditas, solvabilitas, firm size, dan firm growth terhadap profitabilitas perusahaan manufaktur sektor consumer goods yang terdaftar di Bursa Efek Indonesia (BEI) tahun 2015-2019. Penelitian ini menggunakan 42 sampel perusahaan consumer goods melalui metode pemilihan purposive sampling. Data perusahaan diakses melalui website perusahaan, www.idx.co.id serta www.idnfinancials.com. Pengolahan data mengunakan software Eviews11. Hasil dari penelitian menunjukan bahwa Firm Size berpengaruh positif signifikan terhadap profitabilitas. Sedangkan Likuiditas, Solvabilitas, dan Firm Growth menunjukan pengaruh negatif yang tidak signifikan terhadap profitabilitas.
\end{abstract}

Kata Kunci: Profitabilitas (ROE), Likuiditas, Solvabilitas, Firm Size, Firm Growth.

\section{LATAR BELAKANG}

Sebuah perusahaan didirikan dengan tujuan memaksimalkan keuntungan atau profit. Kemampuan perusahaan untuk memperoleh laba dapat disebut sebagai profitabilitas perusahaan (Jaworski \& Czerwonka, 2016). Semakin tinggi nilai rasio profitabilitas, akan semakin tinggi juga tingkat keuntungan yang diperoleh perusahaan pada periode tersebut (Kartikasari \& Merianti, 2016). Oleh karena itu, sangatlah penting bagi perusahaan untuk mengetahui faktorfaktor yang dapat mempengaruhi dan berdampak pada profitabilitas perusahaan.

Dalam menjalankan aktivitasnya, perusahaan membutuhkan suntikan berupa pendanaan yang salah satunya bisa didapatkan melalui hutang pinjaman. Jumlah hutang dengan ekuitas harus proposional. Rasio yang dapat menciptakan tingkat proposional antara ekuitas dengan hutang adalah rasio solvabilitas atau rasio leverage. Rasio solvabilitas digunakan untuk mengukur kemampuan suatu perusahaan untuk membayar kewajibannya, baik jangka pendek maupun jangka panjang, terutama saat mengalami likuidasi (Kartikasari \& Merianti, 2016). Dengan menggunakan hutang dengan tepat dan efisien, akan meningkatkan profitabilitas perusahaan. Pada penelitian yang dilakukan oleh Bhayani, 2010; Janjua et al., 2016; Jaworski \& Czerwonka, 2016; Nanda \& Panda, 2018 dan Nugraha \& Haryanto, 2016 menunjukan hasil likuiditas berpengaruh positif dan signifikan terhadap profitabilitas, Fransisca \& Widjaja, 2019 menemukan hasil likuiditas berpengaruh negatif terhadap ptofitabilitas, sedangkan Alarussi \& 
Alhaderi, 2018; Anissa, 2019; Kaur \& Kaur, 2016; Latha \& Rao, 2017; Novyanny \& Turangan, 2019 dalam penelitiannya menunjukan likuiditas berpengaruh tidak signifikan terhadap profitabilitas.

Dalam memenuhi kewajiban hutangnya, maka diperlukan rasio likuiditas. Rasio likuiditas mengukur kemampuan suatu perusahaan untuk memenuhi kewajibannya dengan memanfaatkan aset likuid yang tersedia, jadi memperhatikan kecukupan likuiditas merupakan indikator yang positif untuk kesehatan keuangan perusahaan (Latha \& Rao, 2017). Dalam penelitiannya, Bhayani, 2010; Kartikasari \& Merianti, 2016 dan Pangestu, 2018 menjelaskan bahwa solvabilitas memiliki pengaruh positif dan signifikan terhadap profitabilitas, Gharaibeh \& Khaled, 2020; Liang \& Natsir, 2019; Pervan \& Mlikota, 2013; Alarussi \& Alhaderi, 2018; Fareed et al., 2017; Fransisca \& Widjaja, 2019; Jaworski \& Czerwonka, 2016; Kaur \& Kaur, 2016; Latha \& Rao, 2017; Nanda \& Panda, 2018 dan Putra \& Badjra, 2015 dalam penelitiannya menemukan solvabilitas memiliki pengaruh negatif signifikan terhadap profitabilitas, tetapi hal ini bertolak belakang dengan penelitian Anggarsari \& Aji, 2018; Gunawan, 2020 dan Arifin \& Indrayang, 2015 yang menemukan hasil solvabilitas memiliki pengaruh tidak signifikan terhadap profitabilitas.

Firm size atau ukuran perusahaan juga dapat mempengaruhi profitabilitas perusahaan. Firm size menjelaskan tingkat efektifnya perusahaan melalui modal kerja yang berasal dari asset perusahaan untuk memaksimalkan nilai perusahaan. Dengan memiliki sumber daya yang besar, perusahaan dapat memperluas pangsa pasar, sehingga meningkatkan keuntungan perusahaan (Natsir \& Yusbardini, 2020). Dalam penelitian yang dilakukan oleh Alarussi \& Alhaderi, 2018; Anggarsari \& Aji, 2018; Fareed et al., 2017; Gharaibeh \& Khaled, 2020; Jaworski \& Czerwonka, 2016; Nanda \& Panda, 2018; Natsir \& Yusbardini, 2020; Nugraha \& Haryanto, 2016 dan Pervan \& Mlikota, 2013 menunjukan hasil firm size berpengaruh positif signifikan terhadap profitabilitas, Kartikasari \& Merianti, 2016 menemukan hasil firm size memiliki pengaruh negatif signifikan terhadap profitabilitas, sedangkan Arifin \& Indrayang, 2015; Fransisca \& Widjaja, 2019; Gunawan, 2020; Latha \& Rao, 2017; Novyanny \& Turangan, 2019; Pangestu, 2018 dan Putra \& Badjra, 2015 menemukan hasil yang berbeda yaitu firm size memiliki pengaruh tidak signifikan terhadap profitabilitas.

Growth ratio atau rasio pertumbuhan dapat mengukur kemampuan suatu perusahaan untuk dapat bisa bersaing dan mempertahankan kedudukannya di dunia industri. Pertumbuhan perusahaan ditujukan dengan tingkat permintaan pasar oleh perusahaan. Apabila tingkat penjualan perusahaan nilainya tinggi, secara otomatis akan mempengaruhi laba perusahaan yang berdampak pada profitabilitas perusahaan. Hal ini akan meningkatkan minat para investor untuk menanamkan investasi di perusahaan (Nugraha \& Haryanto, 2016). Anissa, 2019; Fareed et al., 2017; Fransisca \& Widjaja, 2019; Gharaibeh \& Khaled, 2020; Kaur \& Kaur, 2016 dan Novyanny \& Turangan, 2019 melakukan penelitian dengan hasil growth memiliki pengaruh positif terhadap profitabilitas, tetapi hal sebaliknya ditemukan dalam penelitian Anggarsari \& Aji, 2018; Bhayani, 2010; Nugraha \& Haryanto, 2016 dan Putra \& Badjra, 2015 bahwa growth memiliki pengaruh tidak signifikan terhadap profitabilitas.

Pada kondisi tahun 2020 ini, dunia diperhadapkan dengan pandemi virus Covid-19. Pandemi covid-19 ini sangat berdampak negatif terhadap kondisi perekonomian di Indonesia, tidak hanya di Indonesia tetapi seluruh dunia pun mengalami hal yang sama. Pada laporan world economic outlook yang diterbitkan oleh IMF di bulan Juni yang memperkirakan pertumbuhan global akan mengalami penurunan hingga minus 4,9 persen pada tahun 2020 (Bratadharma, 2020). Industri consumer goods masih mempunyai peluang tumbuh positif. Aksi panic buying yang terjadi pada awal tahun, khususnya pada permintaan produk hiegene, obat-obatan, makanan, dan minuman membuat perusahaan industri consumer goods dapat mempertahankan hidupnya di tengah ancaman pandemi ini (Hidayat, 2020). Oleh karena itu peneliti membatasi penelitian pada perusahaan manufaktur consumer goods. 
Dari pemaparan di atas, penulis melakukan penelitian dengan judul "Pengaruh Likuiditas, Solvabilitas, Firm size, dan Firm Growth terhadap Profitabilitas Pada Perusahaan Manufaktur Sektor Consumer Goods yang Terdaftar di Bursa Efek Indonesia ."

\section{KAJIAN TEORI}

\section{Gambaran Umum Teori}

Du Pont Analysis ini pada dasarnya adalah hubungan antar rasio secara keseluruhan yang menggabungkan data-data dari Neraca dan perhitungan Laba Rugi ke dalam dua ringkasan alat ukur kemampuan menghasilkan laba (profitabilitas) yaitu, ROI dan ROE (Sjahrial, 2006). Trade-off theory merupakan pemikiran perusahaan lebih memilih pembiayaan melalui hutang. Perusahaan memanfaatkan hutang untuk meringankan pembayaran pajak perusahaan yang pada akhirnya dapat meningkatkan profit perusahaan.

\section{Definisi Konseptual Variabel}

Profitabilitas merupakan kemampuan suatu perusahaan untuk menghasilkan profit atau laba dalam periode tertentu. Semakin tinggi nilai rasio profitabilitas, maka akan semakin tinggi pula laba yang dihasilkan perusahaan dalam periode tertentu (Kartikasari \& Merianti, 2016).

Likuiditas mengukur kemampuan suatu perusahaan untuk memenuhi kewajibannya dengan memanfaatkan asset likuid yang tersedia, dengan memperhatikan kecukupa likuiditas merupakan indikator yang positif untuk kesehatan keuangan perusahaan (Latha \& Rao, 2017). Perusahaan yang memiliki likuiditas yang tinggi menghasilkan arus kas bebas yang besar sehingga meningkatkan profitabilitas (Jaworski \& Czerwonka, 2016).

Solvabilitas digunakan untuk mengukur kemampuan suatu perusahaan untuk membayar semua kewajibannya jangka pendek maupun jangka panjang (Kartikasari \& Merianti, 2016). Menurut Olang, 2017 solvabilitas merupakan komposisi hutang dalam struktur modal. Komposisi hutang dengan modal perusahaan harus seimbang.

Firm size atau ukuran perusahaan berperan besar untuk meningkatkan profitabilitas (Latha \& Rao, 2017). Semakin besar perusahaan, semakin besar modal yang diperoleh perusahaan dan akan meningkatkan tingkat profit perusahaan (Kartikasari \& Merianti, 2016)

Firm growth atau pertumbuhan perusahaan adalah mengukur sejauh mana kemampuan perusahaan untuk tumbuh dan berkembang (Fajaria, 2018).

\section{Perumusan Hipotesis}

Likuiditas menggambarkan kemampuan sebuah perusahaan untuk menjalankan kewajiban pembayaran hutang dalam jangka pendek. Perusahaan yang mempunyai tingkat rasio likuiditas yang tinggi menggambarkan bahwa perusahaan tersebut lancar dalam melaksanakan kewajiban pembayaran hutang. Dengan tidak adanya hambatan, perusahaan mampu memaksimalkan keuntungan. Oleh karena itu dapat dirumuskan hipotesis pertama:

\section{$H_{a 1}$ : Likuiditas memiliki pengaruh positif terhadap profitabilitas.}

Solvabilitas atau leverage menggambarkan tentang komposisi dana hutang dengan dana modal suatu perusahaan. Komposisi ini harus seimbang. Perusahaan yang memiliki tingkat leverage yang tinggi akan menghasilkan keuntungan yang besar dengan memanfaatkan hutang tersebut dengan meminimalkan biaya pajak perusahaan, yang akan berdampak dengan profit perusahaan. Sehingga dapat dirumuskan hipotesis kedua:

\section{$\mathrm{H}_{\mathrm{a} 2}$ : Solvabilitas memiliki pengaruh positif terhadap profitabilitas.}

Firm size mengukur besar atau kecilnya suatu perusahaan. Firm size dapat diukur melalui asset yang dimiliki. Jika perusahaan memiliki asset yang besar, maka dapat dikatakan perusahaan yang besar. Besarnya perusahaan dapat meningkatkan keuntungan perusahaan, karena perusahaan dapat memaksimalkan kegiatan operasional yang ditunjang dengan asset 
yang dimilikinya menghasilkan kinerja yang baik yang dapat berdampak dengan nilai profitabilitas perusahaan. Maka dari itu dapat dirumuskan hipotesis ketiga, yaitu:

\section{$\mathrm{H}_{\mathrm{a}}$ : Firm size memiliki pengaruh positif terhadap profitabilitas.}

Pertumbuhan menggambarkan tentang sejauh mana perusahaan dapat tumbuh dan berkembang. Perusahaan yang memiliki peluang pertumbuhan yang besar memiliki reputasi yang baik, yang dapat mempermudah pendanaan serta meningkatkan rasa percaya dari pihak eksternal, hal ini berpengaruh dalam kinerja perusahaan yang lebih baik berdampak dengan keuntungan perusahaan. Pertumbuhan perusahaan dapat digambarkan dengan kinerja penjualannya. Jika pertumbuhan penjualan meningkat akan meningkatkan keuntungan yang diperoleh perusahaan. Dengan pernyataan tersebut, dapat dirumuskan hipotesis yang keempat, yaitu:

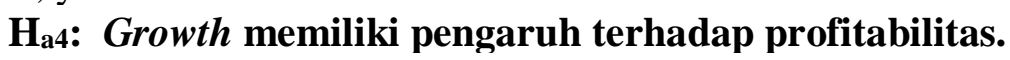

Berdasarkan hipotesis yang telah dirumuskan diatas, maka dapat digambarkan desain penelitian seperti gambar berikut ini:

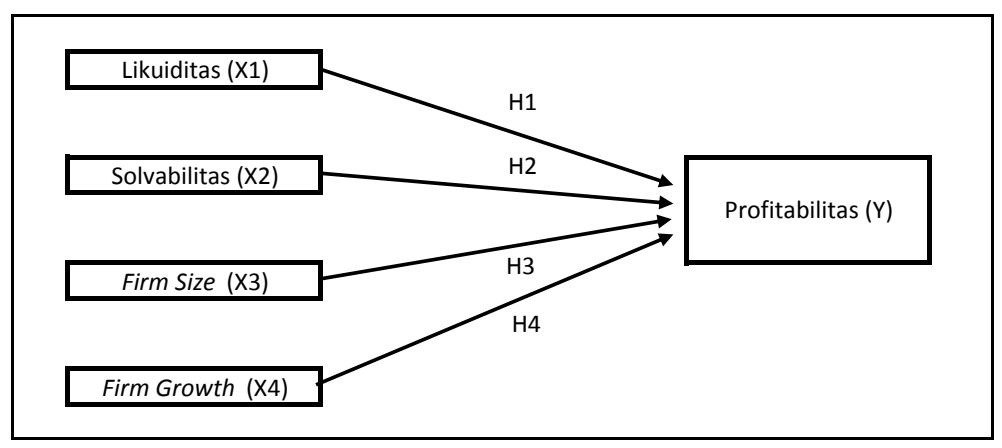

\section{Gambar 1. Desain Penelitian}

\section{METODOLOGI}

Desain penelitian yang digunakan adalah penelitian deskriptif dengan metode kuantitatif. Penelitian ini menggunakan data panel gabungan antara data cross section dan data time series. Subyek penelitian adalah perusahaan manufaktur sektor consumer goods yang terdaftar di Bursa Efek Indonesia periode 2015-2019. Sedangkan objek penelitian adalah profitabilitas yang diukur dengan return on equity (ROE), likuiditas yang diukur dengan current ratio (CR), solvabilitas yang diukur dengan debt to equity ratio (DER), firm size diukur dengan total asset, dan firm growth yang diukur dengan perbandingan total penjualan tahun sekarang dengan tahun yang lalu.

\section{Tabel 1. Operasionalisasi Variabel}

\begin{tabular}{|c|c|l|c|}
\hline Variabel & Ukuran & \multicolumn{1}{|c|}{ Pengertian } & Skala \\
\hline \multirow{2}{*}{ Profitabilitas } & $\begin{array}{c}\text { Return on Equity }=\frac{\text { Net profit }}{\text { Equity }} \\
\text { (Yasser et al., 2011) }\end{array}$ & $\begin{array}{l}\text { Perbandingan antara laba bersih setelah pajak } \\
\text { dengan total ekuitas }\end{array}$ & Ratio \\
\hline Likuditas & $\begin{array}{c}\text { Current Ratio }(\text { CR })=\frac{\text { Current Assets }}{\text { Current Liabilities }} \\
\text { (Anissa, 2019) }\end{array}$ & $\begin{array}{l}\text { Hasil pembagian seluruh aset lancar dengan } \\
\text { seluruh kewajiban lancar }\end{array}$ & Ratio \\
\hline Solvabilitas & Debt to equity ratio $=\frac{\text { Debt }}{\text { Equity }}$ & $\begin{array}{l}\text { Menggambarkan hubungan antara hutang dengan } \\
\text { modal dari pemangku kepentingan yang digunakan } \\
\text { untuk membiayai asset perusahaan }\end{array}$ & Ratio \\
\hline
\end{tabular}




\begin{tabular}{|c|c|l|c|}
\hline Firm Size & $\begin{array}{c}\text { Size of Firm }=\text { Logarithm of Total Assets } \\
\text { (Kaur \& Kaur, 2016) }\end{array}$ & Ukuran dari asset perusahaan & Ratio \\
\hline $\begin{array}{c}\text { Firm } \\
\text { Growth }\end{array}$ & Growth $=\frac{\text { Sales }_{i}-\text { Sales }_{i-1}}{\text { Sales }_{t-1}}$ & $\begin{array}{l}\text { Perhitungan dimana penjualan tahun sekarang } \\
\text { dikurang dengan penjualan tahun lalu kemudian } \\
\text { dibagi dengan penjualan tahun lalu }\end{array}$ & Ratio \\
\hline
\end{tabular}

Teknik pengambilan sampel yang digunakan adalah purposive sampling (nonprobability sampling) dimana peneliti membuat ketentuan dan batasan subyek yang akan dijadikan sampel penelitian. Kriteria pemilihannya yaitu: (1) perusahaan manufaktur yang bergerak di sektor consumer goods yang terdaftar di Bursa Efek Indonesia periode 2015-2019 (2) perusahaan manufaktur sektor consumer goods yang tidak melakukan delisting selama periode 2015-2019 (3) perusahaan manufaktur sektor consumer goods yang mempublikasikan laporan keuangan secara periodik per 31 Desember secara lengkap (4) Perusahaan manufaktur sektor consumer goods yang menyediakan data yang dibutuhkan dalam perhitungan. Dari 62 perusahaan manufaktur sektor consumer goods setelah melalui proses teknik purposive sampling, jumlah sampel yang memenuhi kriteria adalah sebanyak 42 perusahaan selama 5 tahun, sehingga jumlah observasi penelitian sebanyak 210 data.

\section{HASIL ANALISIS DATA}

Uji Multikolinearitas. Uji ini untuk menjelaskan adanya hubungan kuat antar lebih dari dua variabel independen dalam sebuah model regresi berganda dan menghindari terjadinya peristiwa multikolinearias. Menurut Liang \& Natsir, 2019 peristiwa multikolinearitas terjadi akibat nilai korelasi secara masing- masing individu variabel independen menunjukan nilai diatas $0,8(>0,8)$.

Hasil uji multikolinearitas menunjukan bahwa antar variabel independen tidak memiliki korelasi lebih dari 0,8 sehingga dapat disimpulkan bahwa variabel independen, yaitu current ratio, debt to equity ratio, firm size, dan sales growth dalam penelitian ini tidak terjadi peristiwa multikolinearitas.

Analisis Data Statistik Deskriptif. Analisis statistik deskriptif ini dapat digunakan untuk mendeskripsikan suatu data guna mempersiapkan data-data dalam uji yang selanjutnya, serta untuk mengetahui kecenderungan dari kumpulan data sampel yang ada.

Hasil analisis data statistik deskriptif menunjukan nilai rata-rata (mean) yang didapatkan oleh Profitabilitas (variabel dependen) yang diukur dengan Return on Equity (ROE) sebesar 0,16. Standar deviasi yang didapatkan sebesar 0,32 maka dapat diketahui bahwa nilai standar deviasi $>$ mean (lebih dari) dengan arti keberagaman kelompok data. Nilai tengah (median) yang didapatkan sebesar 0,11. Sedangkan, angka profitabilitas tertinggi sebesar 2,25 dan angka profitabilitas (ROE) terendah sebesar -0,69.

Hasil analisis data statistik deskriptif menunjukan nilai rata-rata (mean) yang didapatkan oleh variabel independen likuiditas yang diukur dengan current ratio sebesar 2,61. Standar deviasi yang didapatkan sebesar 1,85. Nilai tengah (median) yang didapatkan sebesar 2,01. Sedangkan, tingkat current ratio tertinggi sebesar 9,28 dan current ratio terendah sebesar 0,15.

Hasil analisis data statistik deskriptif menunjukan nilai rata-rata (mean) yang didapatkan oleh variabel independen solvabilitas yang diukur dengan debt to equity ratio sebesar 0,82. Standar deviasi yang didapatkan sebesar 0,90, Nilai tengah (median) yang didapatkan sebesar 0,62. Sedangkan, tingkat debt to equity ratio tertinggi sebesar 6,31 dan tingkat debt to equity ratio terendah sebesar $-5,02$.

Hasil analisis data statistik deskriptif menunjukan nilai rata-rata (mean) yang didapatkan oleh variabel independen firm size yang diukur melalui total asset sebesar 14,51. Standar deviasi 
yang didapatkan sebesar 2,31. Nilai tengah (median) yang didapatkan sebesar 14,55. Sedangkan, nilai firm size tertinggi sebesar 18,39 dan nilai firm size terendah sebesar 4,22.

Hasil analisis data statistik deskriptif menunjukan nilai rata-rata (mean) yang didapatkan oleh variabel independen firm growth yang diukur melalui total sales sebesar 0,09. Standar deviasi yang didapatkan sebesar 0,33 Nilai tengah (median) yang didapatkan sebesar 0,06. Sedangkan, nilai sales growth tertinggi sebesar 3,23 dan nilai sales growth terendah sebesar 0,75 .

Analisis Model Estimasi Regresi Data Panel. Dalam mengoperasionalkan data panel, terdapat 3 model yang dapat digunakan, yaitu Common Effects Model, Fixed Effects Model, dan Random Effects Model. Maka akan dilakukan Uji Chow (Chow Test), Uji Hausman (Hausman Test), dan Uji Lagrange Multiplier untuk mengetahui model yang terbaik.

Tabel 2. Pemilihan Model Terbaik

\begin{tabular}{|c|c|c|c|}
\hline Uji Chow & Uji Hausman & Uji Lagrange Multiplier & Pemilihan \\
\hline Cross section $F$. & $\begin{array}{l}\text { Cross-Section } \\
\text { Random }\end{array}$ & Cross-Section Breusch Pagan & Model \\
\hline Prob & Prob & Prob (Both) & Terbaik \\
\hline 0,00 & 0,48 & 0,00 & $\begin{array}{c}\text { Random Effect } \\
\text { Model }\end{array}$ \\
\hline
\end{tabular}

Sumber : Hasil pengolahan data menggunakan Eviews 11

Berdasarkan hasil diatas, diketahui persamaan random effect model dapat diperhitungkan melalui rumus berikut:

$\mathrm{ROE}_{\mathrm{it}}=\alpha_{0}+\beta_{1} \mathrm{CR}_{1 \mathrm{it}}+\beta_{2} \mathrm{DER}_{2 \mathrm{it}}+\beta_{3} \mathrm{FIRMIZE}_{3 \mathrm{it}}+\beta_{4} \mathrm{SALES} \mathrm{GROWTH}_{4 \mathrm{it}}+\varepsilon_{\mathrm{it}}+\mu_{\mathrm{i}}$

Analisis Regresi Berganda. Tujuan dari analisis regresi berganda ini untuk mengetahui adanya hubungan atau tidak adanya hubungan antara 2 (dua) variabel independen bahkan bisa lebih variabel independen terhadap variabel dependen.

Tabel 3. Hasil Analisis Regresi Berganda

\begin{tabular}{|c|r|rrr|}
\hline Variabel & Koefisien & Std. Error & t-Statistic & Prob. \\
\hline \hline C & $-0,19$ & 0,19 & $-1,00$ & 0,32 \\
CR & $-0,02$ & 0,02 & $-0,94$ & 0,35 \\
DER & $-0,01$ & 0,04 & $-0,34$ & 0,73 \\
FIRM_SIZE & 0,03 & 0,01 & 2,10 & 0,04 \\
SALES_GROWTH & $-0,06$ & 0,06 & $-0,87$ & 0,38 \\
\hline
\end{tabular}

Sumber : Hasil pengolahan data menggunakan Eviews 11

Berdasarkan hasil analisis regresi berganda, didapatkan persamaan sebagai berikut:

$$
\text { ROE }=-0.19-0.02 \mathrm{CR}-0,01 \mathrm{DER}+\text { 0,03 FIRM_SIZE - 0,06 SALES_GROWTH }
$$

Pada persamaan regresi yang telah ditentukan, didapatkan nilai konstanta $-0,19$. Jika variabel current ratio, debt to equity ratio, firm size, dan sales growth bernilai konstan, maka nilai profitabilitas (ROE) turun sebesar 0,19. Koefisien regresi untuk current ratio $(\mathrm{CR})$ sebesar $-0,02$. Jika nilai current ratio naik satu satuan dan variabel lainnya dianggap konstan, maka profitabilitas (ROE) turun sebesar 0,02 satuan. Koefisien regresi untuk debt to equity ratio (DER) sebesar -0,01. Jika nilai debt to equity ratio naik satu satuan dan variabel lainnya dianggap konstan, maka profitabilitas (ROE) turun sebesar 0,01 satuan. Koefisien regresi untuk firm size sebesar 0,03. Jika nilai firm size naik satu satuan dan variabel lainnya dianggap konstan, maka profitabilitas (ROE) naik sebesar 0,03 satuan. Koefisien regresi untuk sales growth sebesar - 
0,06. Jika nilai sales growth naik satu satuan dan variabel lainnya dianggap konstan, maka profitabilitas (ROE) turun sebesar 0,06 satuan.

Uji-t. Uji t digunakan guna untuk menguji serta mengetahui apakah secara individu variabel independen, yaitu likuiditas, solvabilitas, firm size, dan growth dapat mempengaruhi variabel dependen dalam penelitian, yaitu profitability.

Tabel 4. Hasil Uji-T

\begin{tabular}{|crrr|r|}
\hline Variable & Coefficient & Std. Error & t-Statistic & Prob. \\
\hline \hline C & $-0,19$ & 0,19 & $-1,00$ & 0,32 \\
CR & $-0,02$ & 0,02 & $-0,94$ & 0,35 \\
DER & $-0,01$ & 0,04 & $-0,34$ & 0,73 \\
FIRM_SIZE & 0,03 & 0,01 & 2,10 & 0,04 \\
SALES_GROWTH & $-0,06$ & 0,06 & $-0,87$ & 0,38 \\
\hline
\end{tabular}

Sumber : Hasil pengolahan data menggunakan Eviews 11

Berdasarkan hasil Uji-T diketahui nilai probabilitas untuk variabel independen likuiditas (current ratio) sebesar 0,35 >0,05 (besar dari 0,05) dan diketahui nilai koefisien -0,02. Ha ditolak, maka terdapat pengaruh negatif tetapi tidak signifikan antara likuiditas (current ratio) terhadap profitabilitas (ROE) dengan tingkat keyakinan sebesar 95\%. Nilai probabilitas untuk variabel independen solvabilitas (debt to equity ratio) sebesar 0,73>0,05 (lebih besar dari 0,05) dan nilai koefisien $-0,01$. Ha 2 ditolak, maka terdapat pengaruh negatif dan tidak signifikan antara debt to equity ratio (DER) terhadap profitabilitas (ROE) dengan tingkat keyakinan sebesar $95 \%$. Nilai probabilitas untuk variabel independen firm size sebesar 0,04 < 0,05 (lebih kecil dari 0,05) dan nilai koefisien $0,03 . \mathrm{H}_{0}$ ditolak, maka terdapat pengaruh positif dan signifikan antara firm size terhadap profitabilitas (ROE) dengan tingkat keyakinan sebesar $95 \%$. Nilai probabilitas untuk variabel independen firm growth (Sales_Growth) sebesar 0,38>0,05 (besar dari 0,05) dan nilai koefisien -0,06. Ha4 ditolak, terdapat pengaruh negatif tidak signifikan antara firm growth (Sales_Growth) terhadap profitabilitas (ROE) dengan tingkat keyakinan sebesar 95\%.

Hasil Uji Koefisien Determinasi $\left(\mathbf{R}^{2}\right)$. Uji Koefisien Determinasi ini bertujuan untuk mengetahui besarnya perubahan variasi variabel dependen yang dapat dijelaskan dari variasi variabel independen.

Tabel 5. Uji Koefisien Determinasi $\left(\mathbf{R}^{2}\right)$

\begin{tabular}{|lr|}
\hline R-squared & 0.024472 \\
\hline Adjusted R-squared & 0.005437 \\
\hline Sumber : Hasil pengolahan data menggunakan & Eviews11
\end{tabular}

Hasil dari uji koefisien determinasi, nilai dari $R$-squared adalah sebesar 0.005437 atau $0,54 \%$. Hasil ini menjelaskan bahwa variabel dependen yaitu profitabilitas (ROE) dapat dijelaskan sebesar $0,54 \%$ oleh variabel independen yaitu likuiditas (CR), solvabilitas (DER), firm size, dan firm growth (sales growth). Sedangkan sisanya sebesar 99,46\% dapat dijelaskan oleh variabel lain yang bukan merupakan variabel independen dalam penelitian ini.

\section{DISKUSI}

Pada hasil penelitian yang telah dijelaskan pada hasil uji-T secara parsial, likuiditas memiliki pengaruh negatif tidak signifikan terhadap profitabilitas pada perusahaan manufaktur sektor consumer goods yang terdaftar di Bursa Efek Indonesia (BEI) tahun 2015-2019. Hal ini 
dapat disebabkan oleh adanya laba ditahan dalam pembelian asset yang berlebihan dan pada akhirnya dapat mengurangi keuntungan.. Hasil penelitian ini didukung oleh Alarussi \& Alhaderi, 2018 bahwa likuiditas tidak menunjukan pengaruh yang signifikan terhadap profitabilitas (ROE) karena profitabilitas tidak bergantung pada basis kas, dan likuiditas penting di lembaga keuangan, misalnya bank, tetapi tidak di perusahaan non-keuangan.

Pada hasil penelitian yang telah dijelaskan pada hasil uji-T secara parsial bahwa solvabilitas memiliki pengaruh negatif tidak signifikan terhadap profitabilitas (ROE) pada perusahaan manufaktur sektor consumer goods yang terdaftar di Bursa Efek Indonesia (BEI) tahun 2015-2019. Penelitian ini didukung oleh Anggarsari \& Aji, 2018 dan Gunawan, 2020 disebabkan perusahaan tidak bergantung dengan pinjaman hutang untuk aktivitas perusahaannya. Perusahaan lebih menggunakan dana internal, oleh karena itu besarnya hutang tidak mempengaruhi profitabilitas perusahaan.

Pada hasil penelitian yang telah dijelaskan pada hasil uji-T secara parsial ditemukan firm size memilliki pengaruh positif signifikan terhadap profitabilitas yang pada perusahaan manufaktur sektor consumer goods yang terdaftar di Bursa Efek Indonesia (BEI) tahun 20152019. Hasil yang serupa di temukan oleh Anggarsari \& Aji, 2018; Gharaibeh \& Khaled, 2020 dan Pervan \& Mlikota, 2013. Ketiganya memiliki pendapat bahwa perusahaan yang besar mempunyai kesempatan skala ekonomi besar yang dapat menyesuaikan kondisi pasar dan mengurangi biaya sehingga dapat meningkatkan profitabilitas. Alarussi \& Alhaderi, 2018 juga menemukan hasil yang serupa karena perusahaan besar lebih mudah memasuki pasar dan melakukan pemasaran sehingga dapat meningkatkan profitabilitas.

Pada hasil penelitian yang telah dijelaskan pada hasil uji-T secara parsial, terdapat pengaruh negatif yang tidak signifikan antara firm growth terhadap profitabilitas pada perusahaan manufaktur sektor consumer goods yang terdaftar di Bursa Efek Indonesia (BEI) tahun 2015-2019. Hasil dari penelitian ini didukung oleh Anggarsari \& Aji, 2018; Bhayani, 2010 dan Nugraha \& Haryanto, 2016 bahwa pertumbuhan penjualan (sales growth). Hal ini dapat diakibatkan meningkatnya pengeluaran perusahaan, misalnya penambahan aktiva, peningkatan bahan baku, biaya pemasaran, serta depresiasi nilai rupiah akibat kenaikan bahan baku impor, sehingga penjualan tidak dapat menutupi biaya yang dikeluarkan oleh perusahaan.

\section{PENUTUP}

Penelitian ini memiliki keterbatasan, yaitu subyek penelitian yang digunakan hanya perusahaan manufaktur pada sektor consumer goods. Rentang tahun yang diteliti hanya pada periode 2015-2019, dan variabel dependen pada penelitian ini hanya dijelaskan oleh empat variabel independen yaitu likuiditas, solvabilitas, firm size, dan firm growth. Oleh karena itu, peneliti selanjutnya disarankan untuk memperluas subyek penelitian dengan menambahkan perusahaan atau sector lainnya di luar perusahaan manufaktur sektor barang konsumsi atau consumer goods, menambahkan periode penelitian, dan memperluas variabel independen penelitian dengan menambahkan variabel lainnya yang dapat mempengaruhi profitabilitas, seperti variabel internal maupun eksternal perusahaan. Bagi para investor dapat mempertimbangkan rasio keuangan selain variabel yang ada di dalam penelitian ini, karena masih banyak faktor-faktor yang mempengaruhi profitabilitas. Dalam hasil penelitian ini, firm size memiliki pengaruh positif yang signifikan terhadap profitabilitas perusahaan. Diharapkan manajemen perusahaan perlu meningkatkan kinerjanya dalam kualitas dan kuantitas seluruh asset sebagai indikator ukuran perusahaan, sehingga asset perusahaan dapat memberikan kontribusi yang maksimal untuk meningkatkan profit perusahaan. Dalam penelitian ini, firm growth memiliki pengaruh paling besar terhadap profitabilitas (ROE). Diharapkan perusahaan memperhatikan tingkat pertumbuhan perusahaan dalam penjualan. Serta Diharapkan perusahaan 
dapat mengetahui faktor-faktor yang mempengaruhi profitabilitas guna untuk mengantisipasi keadaan yang tidak diinginkan, seperti dampak besar dari pandemi covid-19 saat ini.

\section{DAFTAR PUSTAKA}

Alarussi, A. S., \& Alhaderi, S. M. (2018). Factors affecting profitability in Malaysia. Journal of Economic Studies, 45(3), 442-458. https://doi.org/10.1108/JES-05-2017-0124

Anggarsari, L., \& Aji, T. S. (2018). Pengaruh ukuran perusahaan, leverage , likuiditas, perputaran modal kerja dan pertumbuhan penjualan terhadap profitabilitas(sektor industri barang dan konsumsi yang terdaftar di bursa efek indonesia periode 2013-2016). Jurnal Ilmu Manajemen, 6(4), 542-549.

Anissa, A. R. (2019). Pengaruh Perputaran Modal Kerja Terhadap Profitabilitas Pada Perusahaan Manufaktur Yang Terdaftar Di Bursa Efek Indonesia. Jurnal Riset Manajemen Sains Indonesia (JRMSI), 10(1), 125-145. https://doi.org/10.35906/jm001.v4i2.279

Arifin, A. Z., \& Indrayang, P. (2015). Dampak kebijakan modal kerja,. Jurnal Ekonomi, XX(01), 20-35.

Bhayani, S. J. (2010). Determinant of Profitability in Indian Cement Industry: An Economic Analysis. South Asian Journal of Management, 17(4), 6-10.

Bratadharma, A. (2020). Perlunya Menjaga Likuiditas saat Pandemi Covid-19. Mediacom.Id. https://www.medcom.id/ekonomi/keuangan/1bVjBPXb-perlunya-menjaga-likuiditas-saatpandemi-covid-19

Fajaria, A. Z. (2018). The Effect of Profitability, Liquidity, Leverage and Firm Growth of Firm Value with its Dividend Policy as a Moderating Variable. International Journal of Managerial Studies and Research, 6(10), 55-69. https://doi.org/10.20431/23490349.0610005

Fareed, Z., Ali, Z., Shahzad, F., Nazir, M. I., \& Ullah, A. (2017). Determinants of Profitability: Evidence from Power and Energy Sector. Studia Universitatis Babe-Bolyai Oeconomica, 61(3), 59-78. https://doi.org/10.1515/subboec-2016-0005

Fransisca, E., \& Widjaja, I. (2019). Pengaruh Leverage, Likuiditas, Pertumbuhan Penjualan dan Ukuran Perusahaan Terhadap Profitabilitas Perusahaan Manufaktur. Jurnal Manajerial Dan Kewirausahaan, 1(2), 199-206.

Gharaibeh, O. K., \& Khaled, M. H. B. (2020). "Determinants of profitability in Jordanian services companies." Investment Management and Financial Innovations, 17(1), 277-290. https://doi.org/10.21511/imfi.17(1).2020.24

Gunawan, H. (2020). Pengaruh Aktivitas, Solvabilitas dan Ukuran Perusahaan Terhadap Profitabilitas Perusahaan Manufaktur Sub Sektor Makanan dan Minuman di Bursa Efek Indonesia Tahun 2012-2017. Jurnal Manajemen Bisnis Dan Kewirausahaan, 4(2), 81-86.

Hidayat, A. (2020). Sektor industri consumer goods masih optimistis tumbuh di tengah ancaman virus corona. IndustriKontan.Co.Id. https://industri.kontan.co.id/news/sektor-industriconsumer-goods-masih-optimistis-tumbuh-di-tengah-ancaman-virus-corona

Janjua, A. R., Asghar, A., Munir, U., Raza, A., Akhtar, N., \& Shahzad, K. (2016). Influence of Liquidity on Profitability of Cement Sector: Indication from Firms Listed in Pakistan Stock Exchange. Business Management Dynamics, 6(5), 1-12. www.bmdynamics.com

Jaworski, J., \& Czerwonka, L. (2016). Relationship Between Profitability and Liquidity of. November, 15-16.

Kartikasari, D., \& Merianti, M. (2016). The Effect of Leverage and Firm Size to Profitability of Public Manufacturing Companies in Indonesia. International Journal of Economics and Financial Issues |, 6(2), 409-413. http:www.econjournals.com

Kaur, N., \& Kaur, J. (2016). Determinants of Profitability of Automobile Industry in India. 
Journal of Commerce and Accounting Research, 5(3). https://doi.org/10.21863/jcar/2016.5.3.034

Latha, M., \& Rao, S. N. (2017). Determinants of profitability: Evidence from listed companies in the bse-fmcg. International Journal of Economic Perspectives, 11(3), 1264-1272. http://www.econ-society.org

Liang, I., \& Natsir, K. (2019). Pengaruh Profitabilitas, Struktur Aktiva, Dan Ukuran Perusahaan Terhadap Struktur Modal. Jurnal Manajerial Dan Kewirausahaan, 1(3), 481-488.

Nanda, S., \& Panda, A. K. (2018). The determinants of corporate profitability: an investigation of Indian manufacturing firms. International Journal of Emerging Markets, 13(1), 66-86. https://doi.org/10.1108/IJoEM-01-2017-0013

Natsir, K., \& Yusbardini, Y. (2020). The Effect of Asset Structure and Firm Size on Firm Value with Capital Structure as Intervening Variable. Advances in Economics, Business and Management Research, 145, 218-224. http://creativecommons.org/licenses/by-nc/4.0/

Novyanny, M. C., \& Turangan, J. A. (2019). Pengaruh Likuiditas, Ukuran Perusahaan, Umur Perusahaan, dan Pertumbuhan Perusahaan Terhadap Profitabilitas Pada Perusahaan Jasa Sektor Perdagangan, Jasa, \& Investasi yang Terdaftar Pada Bursa Efek Indonesia. Jurnal Manajerial Dan Kewirausahaan, 1(1).

Nugraha, P. S., \& Haryanto, A. M. (2016). Analisis Pengaruh Sales Growth, ROE, SIZE, TATO, dan Current Ratio Terhadap ROA dan Terhadap Beta Akuntasi Studi Kasus Pada Perusahaan Manufaktur yang Terdaftar di BEI Periode 2010-2014). Diponegoro Journal of Management, 5(1), 1-12. http://ejournal-s1.undip.ac.id/index.php/dbr

Olang, M. (2017). Effect of Financial Leverage on Profitability of Firms Listed in the Nairobi Securities Exchange. International Journal of Science and Research (IJSR), 6(7), 290-295. https://doi.org/10.21275/art20175033

Pangestu, A. (2018). Pengaruh Aktivitas Rasio, Ukuran Perusahaan, Struktur Modal, Likuiditas dan Debt Ratio Terhadap Profitabilitas Sub Sektor Makanan dan Minuman di BEI 20092016. Jurnal Manajemen Bisnis Dan Kewirausahaan, 02(3), 37-45.

Pervan, M., \& Mlikota, M. (2013). What determines the profitability of companies: Case of Croatian food and beverage industry. Ekonomska Istrazivanja, 26(1), 277-286. https://doi.org/10.1080/1331677X.2013.11517602

Putra, A., \& Badjra, I. (2015). Pengaruh Leverage, Pertumbuhan Penjualan Dan Ukuran Perusahaan Terhadap Profitabilitas. E-Jurnal Manajemen Universitas Udayana, 4(7), 2052-2067.

Sjahrial, D. (2006). Pengantar Manajemen Keuangan (Edisi Pert). Mitra Wacana Media.

Yasser, Q. R., Entebang, H. A., \& Mansor, S. A. (2011). Corporate Governance and Firm Performance in Pakistan: The Case of Karachi Stock Exchange (KSE)-30. Journal of Economics and International Finance, 3(8), 482-491. https://doi.org/10.2139/ssrn.2551636 